\title{
Genetic Resistance to Cucurbit Leaf Crumple Virus in Melon
}

\author{
James D. McCreight ${ }^{1}$ and Hsing-Yeh Liu \\ U.S. Agricultural Research Station, U.S. Department of Agriculture, \\ Agricultural Research Service, 1636 E. Alisal Street, Salinas, CA 93905
}

\author{
Thomas A. Turini \\ University of California Cooperative Extension, Imperial County, 1050 E. \\ Holton Road, Holtville, CA 92250-9615
}

Additional index words. Bemisia tabaci biotype B, cantaloupe, muskmelon, disease, begomovirus, geminivirus, Cucurbit leaf curl virus, inheritance

\begin{abstract}
Cucurbit leaf crumple virus $(\mathrm{CuLCrV})$ is a geminivirus transmitted by Bemisia tabaci (Gennadius) biotype B (SPW-B) and common in melons (Cucumis melo L.) planted from July through September in the desert southwestern United States. Symptoms include chlorotic leaf spots, leaf curling and crumpling, and interveinal yellowing, and plants may be stunted. Melon breeding line MR-1, and six plant introductions (PIs; PI 124111, PI 124112, PI 179901, PI 234607, PI 313970, and PI 414723) exhibited partial resistance to $\mathrm{CuLCrV}$ in naturally infected field tests and controlled inoculation greenhouse tests. PI 236355 was completely resistant in two greenhouse tests. Partially resistant plants exhibited chlorotic spots, or mild expression of other typical $\mathrm{CuLCrV}$ symptoms; all such plants were positive for presence of virus using polymerase chain reaction analysis with a $\mathrm{CuLCrV}$-specific primer pair from the $\mathrm{BC} 1$ region. Genetic resistance to $\mathrm{CuLCrV}$ in melon was recessive. Field and greenhouse data from $F_{1}, F_{2}$, and backcrosses of the $F_{1}$ to 'Top Mark' and PI 313970 demonstrated a single, recessive gene for resistance to $\mathrm{CuLCrV}$. Progenies from crosses of four partially resistant cultigens with 'Top Mark' were susceptible. Resistance in PI 313970 appeared to be allelic, with resistance in the other six cultigens based on $\mathrm{F}_{1}$ data. The name cucurbit leaf crumple virus and symbol culcrv are proposed for this gene.
\end{abstract}

Sweetpotato whitefly, Bemisia tabaci (Gennadius), adversely affects yield and quality of a wide range of vegetable and agronomic crops worldwide directly through feeding damage or indirectly as virus vectors (Henneberry et al., 1998). It is known to transmit 111 virus species (Jones, 2003). Six sweetpotato whitefly-transmitted begomoviruses of melon (Cucumis melo L.) have appeared in commercial melon fields in the southwestern United States, western Mexico, and Central America since 1977 (Table 1). Squash leaf curl virus (SLCV), first reported in 1977 (Flock and Mayhew, 1981), is notable among the group for the fact that melon was not a host in open commercial fields or experimentally in controlled-inoculation greenhouse tests (Cohen et al., 1983), but SLCV was recently detected with polymerase chain reaction (PCR) using SLCV-

Received for publication 24 June 2007. Accepted for publication 29 Aug. 2007.

Mention of a trade name, proprietary product, or specific equipment does not constitute a guarantee or warranty by the U.S. Department of Agriculture and does not imply its approval to the exclusion of other products that may be suitable.

We thank Patti Fashing for assistance in the field and greenhouse tests, and Jeff Wasson and John Sears for assistance in the greenhouse and laboratory tests.

${ }^{1}$ To whom reprint requests should be addressed; e-mail james.mccreight@ars.usda.gov specific primers in commercial melon plants in Imperial Valley (R.L. Gilbertson, pers. comm.). Cucurbit leaf crumple virus (CuLCrV) (Guzman et al., 2000) and cucurbit leaf curl virus (Brown et al., 2000) are identical geminiviruses, with more than $98 \%$ similarity based on percent nucleotide and amino acid similarities for open reading frames, and are distinct from SLCV and melon chlorotic leaf curl virus $(\leq 92 \%$ and $91 \%$ respectively) (Brown et al., 2002). None of the six viruses has caused significant, widespread economic losses to melon production in these areas (T.A. Turini, unpublished). Genetic resistance has not been reported to any of these six viruses, with the possible exception being the original SLCV strain, which did not infect melon.

Cucurbit leaf crumple virus symptoms include chlorotic leaf spots and terminal buds, leaf curling and crumpling, and interveinal yellowing. In addition, plants may be stunted in size (Fig. 1). When severe and widespread $\mathrm{CuLCrV}$ symptoms were observed in commercial melon fields early in the season in several succeeding years, the fields recovered with no observable reduction in yield (T.A. Turini, unpublished). Experimental melon plantings in Fall 2003 at the University of California, Desert Research and Education Center (DREC), El Centro, $\mathrm{CA}$, and the University of Arizona, Yuma Agricultural Research Center, Yuma, AZ, exhibited severe and uniform symptoms sim- ilar to SLCV and CuLCrV. We report here the identification of $\mathrm{CuLCrV}$ at these two sites, resistance in field and greenhouse tests to $\mathrm{CuLCrV}$ in a limited number of melon cultigens [cultivars, breeding lines, and plant introductions (PIs)], and inheritance of resistance in melon.

\section{Materials and Methods}

Germplasm evaluation and genetic studies of resistance to $\mathrm{CuLCrV}$ were done in naturally infected field and controlled-inoculation greenhouse tests. Germplasm evaluation and inheritance studies were done in adjoining field plots at DREC. The field studies were repeated and extended in a series of greenhouse tests at Salinas.

Germplasm evaluation. Thirteen cultigens (Table 2) were evaluated in naturally infected field tests in 2003 and 2004 arranged in a randomized complete block design with three replications. The tests were planted on 11 Sept. and 15 Sept., respectively, and were irrigated as needed using a subsurface drip. Each plot (one cultigen per plot) was $3.7 \mathrm{~m}$ long and consisted of three hills spaced $0.9 \mathrm{~m}$ apart with $0.9-\mathrm{m}$ buffers on each end; beds were $2.0 \mathrm{~m}$ wide. Two seeds were planted per hill. The tests were evaluated on 20 Nov. and 7 Nov. respectively. Cucurbit leaf crumple virus symptoms were evaluated on a plot basis and were noted as present (susceptible) or absent (resistant).

Twenty-three cultigens were evaluated in four controlled-inoculation greenhouse tests in 2004 (Table 2). Each test was arranged in a completely randomized design for inoculation using sweetpotato whitefly biotype B (SPW-B) (Brown and Costa, 1992), as described later. The number of plants of each cultigen varied as a result of seed availability and "germinability," and ranged from as few as two to as many as five in a given test. Plants were individually evaluated several times from 10 through $28 \mathrm{~d}$ postinoculation for the presence or absence of virus symptoms. Every plant was assayed for the presence of virus using the PCR protocol described later.

Aviruliferous SPW-B colonies were maintained on virus-free 'Perlita' melon plants in whitefly-proof cages in an isolated greenhouse. Identity of the SPW-B colony was determined and periodically verified using esterase isozyme electrophoresis (Liu et al., 1992). The CuLCrV field isolate was maintained by serial transfer to 'Perlita' melon using SPW-B. All virus inoculations were done by mass transfer of SPW-B from a healthy colony to $\mathrm{CuLCrV}$-infected 'Perlita' plants, where they fed for at least $24 \mathrm{~h}$ before subsequent transfer to healthy plants for maintenance of $\mathrm{CuLCrV}$, or to test plants as described later.

Genetic study. There were three aspects to the genetic study. First was the determination of the inheritance of resistance to $\mathrm{CuLCrV}$ in PI 313970 using the $F_{1}$ and segregating generations from crosses with 'Top Mark' (Table 3). This study had been planted in the 
Table 1. Six begomoviruses of melon in the North and Central Americas.

\begin{tabular}{|c|c|c|}
\hline Virus & Year and area first observed & Reference \\
\hline Squash leaf curl virus ${ }^{\mathrm{z}}$ & 1977, Imperial Valley, CA & Flock and Mayhew, 1981 \\
\hline $\begin{array}{l}\text { Squash mild leaf curl virus } \\
\text { (syn., Melon leaf curl virus) }\end{array}$ & 1985, Imperial Valley, CA & $\begin{array}{l}\text { Duffus et al., 1985; ICTVdB } \\
\text { Management, } 2006\end{array}$ \\
\hline Watermelon curly mottle virus & 1982, Yuma, AZ & Brown and Nelson, 1986 \\
\hline Cucurbit leaf crumple virus & 1999, Imperial Valley, CA & Guzman et al., 2000 \\
\hline Cucurbit leaf curl virus & $\begin{array}{l}\text { 1998, Yuma, AZ } \\
\text { 1998, Coahuila, Mexico }\end{array}$ & Brown et al., 2000 \\
\hline Melon chlorotic leaf curl virus & 2000, Guatemala & Brown et al., 2001 \\
\hline
\end{tabular}

${ }^{\mathrm{z}}$ Melon was not a host of squash leaf curl virus when first reported.

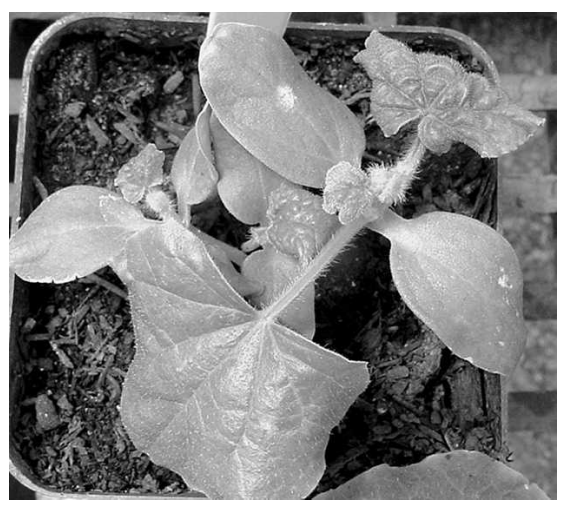

Fig. 1. Cucurbit leaf crumple virus-infected melon plants showing crumpling, curling, stunting, and yellowing leaf symptoms followed by sweetpotato whitefly (Bemisia tabaci) biotype $\mathrm{B}$ inoculation.

field at DREC in Fall 2003 initially to determine the inheritance of resistance in PI 313970 to an apparent new race of powdery mildew incited by Podosphaera xanthii on melon (McCreight et al., 2005), when PI 313970 was observed to be resistant to $\mathrm{CuLCrV}$. The study was repeated in a second field planting in Fall 2004 and in a greenhouse. Emphasis was placed on PI 313970 as a source of resistance to $\mathrm{CuLCrV}$ because it is a source of other disease and insect resistances of importance in the desert Southwest United States: races 1, 2, and $\mathrm{S}$ of $P$. xanthii (McCreight, 2003; McCreight and Coffey, 2007; McCreight et al., 2005), Lettuce infectious yellows virus (McCreight, 2000), and SPW-B (Boissot et al., 2003).

The field tests consisted of completely randomized blocks with seven replications of the susceptible 'Top Mark' (TM), PI 313970 (PI), and their $F_{1}, F_{2}$, and backcross progenies as described earlier. Each replication included one plot of each parent, four (2003) or two (2004) plots of reciprocal $F_{1}$ progenies, five plots of one $F_{2}$ progeny, one plot of the backcross to 'Top Mark' ( $\left.\mathrm{BC}_{\mathrm{TM}}\right)$, and two plots of the backcross to PI $313970\left(\mathrm{BC}_{\mathrm{PI}}\right)$. Each plant was individually evaluated for CuLCrV symptoms. In 2003, plants were rated as asymptomatic, symptomatic, or uncertain (some leaves or shoots that did not appear to be healthy, yet did not express typical $\mathrm{CuLCrV}$ symptoms). A fourth category, chlorotic spots on leaves, was added in 2004.
Table 2. Reaction of 27 melon cultigens to Cucurbit leaf crumple virus in field (natural infection) and greenhouse tests (controlled inoculation).

\begin{tabular}{lcc}
\hline & Field & $\begin{array}{c}\text { Greenhouse }^{\mathrm{y}} \\
\text { (no. infected } \\
\text { plants/total }\end{array}$ \\
Cultigen & $\begin{array}{c}\text { (2003/2004) } \\
\text { no. plants) }\end{array}$ \\
\hline $\begin{array}{l}\text { Cultivars and breeding lines } \\
\text { Amarillo }\end{array}$ & - & $4 / 4$ \\
Edisto 47 & $\mathrm{S} / \mathrm{S}$ & $4 / 4$ \\
Esteem & - & $8 / 10$ \\
Freeman Cucumber & - & $5 / 5$ \\
Fuyu 3 & $\mathrm{R} / \mathrm{S}$ & $2 / 2$ \\
Hara Madhu & $-/ \mathrm{S}$ & - \\
Impac & $\mathrm{S} / \mathrm{S}$ & $9 / 10$ \\
Moscatel Grande & - & $4 / 5$ \\
Negro & - & $5 / 5$ \\
Perlita & - & $13 / 15$ \\
PMR 5 & $\mathrm{S} / \mathrm{S}$ & $5 / 5$ \\
Punjab Hybrid & $-/ \mathrm{S}$ & - \\
Punjab Sun & $-/ \mathrm{S}$ & - \\
Seminole & - & $4 / 4$ \\
Sol Dorado & - & $10 / 10$ \\
Sol Real & - & $10 / 10$ \\
Top Mark & $\mathrm{S} / \mathrm{S}$ & $45 / 48$ \\
Védrantais & - & $3 / 5$ \\
WMR 29 & $\mathrm{S} / \mathrm{S}$ & $5 / 5$ \\
Plant introductions & & \\
MR-1 & $\mathrm{R} / \mathrm{R}$ & $0 / 6$ \\
PI 124111 & - & $2{ }^{\mathrm{x} / 13}$ \\
PI 124112 & $\mathrm{S} / \mathrm{R}$ & $2^{\mathrm{x}} / 15$ \\
PI 179901 & - & $1 / 15$ \\
PI 234607 & - & $5 / 12$ \\
PI 236355 & - & $0 / 4$ \\
PI 313970 & $\mathrm{R} / \mathrm{R}^{\mathrm{x}}$ & $3^{\mathrm{w}} / 24$ \\
PI 414723 & $\mathrm{R} / \mathrm{R}^{\mathrm{x}}$ & $6 / 15$ \\
\hline
\end{tabular}

${ }^{2}$ Rated on a plot basis; $R$, resistant; $S$, susceptible. yPlants individually evaluated; composite of five tests.

${ }^{\mathrm{x}}$ Chlorotic spots only.

wOne plant had chlorotic spots only; two plants had mild symptoms.

PI, plant introduction.

The greenhouse inheritance study was done in a series of three tests as described earlier. One test included 'Top Mark' (10 plants) and PI 313970 (26 plants), two reciprocal $\mathrm{F}_{1}$ progenies (10 plants each), $\mathrm{BC}_{\mathrm{TM}}$ (11 plants), and $\mathrm{BC}_{\mathrm{PI}}$ (26 plants). Two tests included either 5 or 10 plants of PI 313970 and 'Top Mark', and 50 plants of two $F_{2}$ families (one family per test); one of the $\mathrm{F}_{2}$ families was used in the two field tests. Plants were individually evaluated for presence or absence of symptoms.

The second aspect of the genetic study determined the control (dominant or recessive) of resistance in three other cultigens using $F_{1}$ progeny from crosses with 'Top Mark' (Table 4). The third and final aspect of the genetic study determined allelism of resistance in PI 313970 with that observed in six other sources of resistance to $\mathrm{CuLCrV}$ (Table 5). These two aspects were done in greenhouse tests as described earlier.

All $F_{1}, F_{2}$, and backcross progenies used in the field and greenhouse tests were produced using standard hand pollination techniques for melon (McCreight et al., 1992; Robinson and Decker-Walters, 1997). Segregation data were analyzed using chi-square analysis with the Yates correction when the expected number in a class was less than 20 (Yates, 1931).

Virus identification and confirmation. Symptomatic melon leaf samples were taken from naturally infected 'Top Mark' plants grown in the field tests at DREC in 2003 and 2004. Total nucleic acids were isolated from $100 \mathrm{mg}$ infected melon leaf tissue according to the method described by Li et al. (1998). The PCR parameters used to amplify the CuLCrV DNA fragment were as follows: an initial denaturing step at $94{ }^{\circ} \mathrm{C}$ for $5 \mathrm{~min}$ followed by $94{ }^{\circ} \mathrm{C}, 40 \mathrm{~s}$ for denaturing; $60{ }^{\circ} \mathrm{C}$, $40 \mathrm{~s}$ for annealing; and $72{ }^{\circ} \mathrm{C}, 1 \mathrm{~min}$ for extension for 35 cycles, with a final extension step of $72{ }^{\circ} \mathrm{C}$ for $10 \mathrm{~min}$. Polymerase chain reaction-amplified DNA fragments were analyzed by electrophoresis in $1 \%$ agarose gels in $1 \times$ Tris-acetate (TAE) buffer ( $40 \mathrm{~mm}$ Trisacetate and $2 \mathrm{~mm}$ ethylenediamine tetraacetic acid; $\mathrm{pH}, 8.0$ ), stained with ethidium bromide, and visualized with ultraviolet light. The primer pairs FA-908 (5'-ACCCCGTG TATGCGACATTG-3'), RA1-1419 (5' -CG ACGAATAGACTTGGACTGCG-3'), and RA2-1601 (5'-AGGAATCCCGTCAATCGT GC-3') were designed from the sequence of CuLCrV DNA-A component (GenBank accession no. AF256200) to amplify AC2 and $\mathrm{AC} 3$ open reading frames. The specific primer pair for $\mathrm{CuLCrV}, \mathrm{FB}-1401$ (5'-TGC TATGCTCACGGGGATTTA- ${ }^{\prime}$ ) and RB2437 (5'-TCACATTCTCTTCGCCACTCG G-3'), was designed from the sequence of CuLCrV DNA-B component (GenBank accession no. AF327559). The amplified products from $\mathrm{AC} 2$ and $\mathrm{AC} 3$ open reading frames were purified using QIAquick Gel Extraction Kit (QIAGEN, Valencia, CA) and were sequenced by a commercial company (MCLAB, South San Francisco, CA). Sequences were analyzed by the program MacVector 7.0 (Accelrys, San Diego, CA)

\section{Results and Discussion}

Polymerase chain reaction detection of cucurbit leaf crumple virus. The CuLCrVspecific primer pair from the $\mathrm{BC} 1$ region was amplified by PCR. A product size of $\approx 1000$ bp was expected (Fig. 2, lane 3). No products were found in similar preparations from healthy plants (Fig. 2, lane 2). The expected product sizes from primer pairs used to amplify AC2 and AC3 open reading frames were obtained (Fig. 2, lanes 4 and 5). The sequence analysis of $\mathrm{AC} 2$ and $\mathrm{AC} 3$ revealed 
Table 3. Reactions of 'Top Mark', PI 313970, and their $\mathrm{F}_{1}, \mathrm{~F}_{2}$, and backcross (BC) families to Cucurbit leaf crumple virus in field and greenhouse tests, number plants.

\begin{tabular}{lrcccrr}
\hline \multicolumn{7}{c}{ Field 2003 } \\
\hline Entry & Asymptomatic & Uncertain & Symptomatic & Expected $^{\mathrm{z}}$ & $\chi^{2}$ & $P$ \\
\hline Top Mark (TM) & 0 & 0 & 0 & All S & & \\
PI $313970(\mathrm{PI})$ & 18 & 0 & 0 & All A & & \\
$\mathrm{F}_{1}(\mathrm{TM} \times \mathrm{PI})$ & 1 & 0 & 17 & All S & & \\
$\mathrm{F}_{1}(\mathrm{PI} \times \mathrm{TM})$ & 2 & 1 & 51 & All S & \\
$\mathrm{F}_{2}(\mathrm{TM} \times \mathrm{PI})$ & 15 & 1 & 63 & $1 \mathrm{~A}: 3 \mathrm{U}+\mathrm{S}$ & $1.22^{\mathrm{y}}$ & 0.27 \\
& & 0 & 15 & $1 \mathrm{~A}+\mathrm{U}: 3 \mathrm{~S}$ & $0.71^{\mathrm{y}}$ & 0.42 \\
$\mathrm{BC}_{\mathrm{TM}}$ & 0 & 0 & 17 & $1 \mathrm{~A}: 1 \mathrm{~S}+\mathrm{S}$ & $0.46^{\mathrm{y}}$ & 0.50 \\
$\mathrm{BC}_{\mathrm{PI}}$ & 15 & 3 & & $1 \mathrm{~A}+\mathrm{U}: 1 \mathrm{~S}$ & $0.000^{\mathrm{y}}$ & $>0.99$ \\
& & & & & &
\end{tabular}

Field 2004

\begin{tabular}{|c|c|c|c|c|c|c|c|}
\hline Entry & Asymptomatic & Uncertain & $\begin{array}{c}\text { Chlorotic } \\
\text { spots }\end{array}$ & Symptomatic & Expected $^{\mathrm{z}}$ & $\chi^{2}$ & $P$ \\
\hline Top Mark (TM) & 3 & 2 & 0 & 15 & All S & & \\
\hline PI 313970 (PI) & 11 & 3 & 18 & 0 & All A & & \\
\hline $\mathrm{F}_{1}(\mathrm{TM} \times \mathrm{PI})$ & 6 & 0 & 0 & 24 & All S & & \\
\hline $\mathrm{F}_{1}(\mathrm{PI} \times \mathrm{TM})$ & 4 & 1 & 0 & 28 & All S & & \\
\hline $\mathrm{F}_{2}(\mathrm{TM} \times \mathrm{PI})$ & 38 & 11 & 7 & 113 & $\begin{array}{l}1 \mathrm{~A}: 3 \mathrm{U}+\mathrm{C}+\mathrm{S} \\
1 \mathrm{~A}+\mathrm{U}: 3 \mathrm{C}+\mathrm{S}\end{array}$ & $\begin{array}{l}0.57 \\
1.44\end{array}$ & $\begin{array}{l}0.46 \\
0.24\end{array}$ \\
\hline $\mathrm{BC}_{\mathrm{TM}}$ & 2 & 1 & 0 & 19 & All S & & \\
\hline $\mathrm{BC}_{\mathrm{PI}}$ & 14 & 0 & 9 & 34 & $1 \mathrm{~A}: 1 \mathrm{U}+\mathrm{C}+\mathrm{S}$ & $14.8^{\mathrm{y}}$ & $<0.001$ \\
\hline
\end{tabular}

Greenhouse 2004 ${ }^{\mathrm{x}}$

\begin{tabular}{lccccrr}
\hline Entry & Asymptomatic & Chlorotic spots & Symptomatic & Expected $^{z}$ & $\chi^{2}$ & $P$ \\
\hline Top Mark (TM) & 1 & 3 & 37 & All S & & \\
PI 313970 (PI) & 31 & 8 & 2 & All A & & \\
$\mathrm{F}_{1}(\mathrm{TM} \times \mathrm{PI})$ & 0 & 2 & 8 & All S & & \\
$\mathrm{F}_{1}(\mathrm{PI} \times \mathrm{TM})$ & 0 & 1 & 9 & All S & & \\
$\mathrm{F}_{2}(\mathrm{TM} \times \mathrm{PI})-1$ & 16 & 6 & 27 & $1 \mathrm{~A}: 3 \mathrm{C}+\mathrm{S}$ & $1.15^{\mathrm{y}}$ & 0.28 \\
$\mathrm{~F}_{2}(\mathrm{TM} \times \mathrm{PI})-2$ & 13 & 0 & 37 & $1 \mathrm{~A}: 3 \mathrm{C}+\mathrm{S}$ & $0.00^{\mathrm{y}}$ & $>0.99$ \\
$\mathrm{BC}_{\mathrm{TM}}$ & 1 & 1 & 9 & All S & & \\
$\mathrm{BC}_{\mathrm{PI}}$ & 9 & 9 & 8 & $1 \mathrm{~A}: 1 \mathrm{C}+\mathrm{S}$ & $1.88^{\mathrm{y}}$ & 0.18 \\
\hline
\end{tabular}

${ }^{\mathrm{z}} \mathrm{A}$, asymptomatic; $\mathrm{C}$, chlorotic spots; $\mathrm{S}$, symptomatic; $\mathrm{U}$, uncertain symptoms.

${ }^{\mathrm{y}}$ Yates correction applied.

${ }^{\mathrm{x}}$ Composite of three tests.

$\mathrm{BC}$, backcross; PI, plant introduction.

Table 4. Reactions of susceptible 'Top Mark', putative resistant cultigens, and their $F_{1}$ progenies to Cucurbit leaf crumple virus in a greenhouse test.

\begin{tabular}{lcc}
\hline & \multicolumn{2}{c}{ No. of plants } \\
\cline { 2 - 3 } Entry & Asymptomatic & Symptomatic \\
\hline Top Mark & 0 & 7 \\
PI 124111 & 4 & 3 \\
PI 179901 & 7 & 0 \\
PI 234607 & 0 & 2 \\
F PI 124111 & & \\
$\quad$ × Top Mark & 11 & 8 \\
F PI 179901 & 2 & 4 \\
$\quad$ × Top Mark & 2 & \\
F PI 234607 & 3 & 15 \\
$\quad \times$ Top Mark & 3 & \\
\hline
\end{tabular}

PI, plant introduction.

a high degree of sequence identity with CuLCrV (100\% and $99.0 \%$ for nucleotides, and $100 \%$ and $97.7 \%$ for amino acids respectively). From the PCR and sequence analyses we determined that the virus isolate present at DREC and Yuma, and used in the subsequent greenhouse studies was $\mathrm{CuLCrV}$.

Melon cultigen evaluation. The 19 cultivars and breeding lines included in these studies proved susceptible to $\mathrm{CuLCrV}$ in the field and greenhouse tests (Table 2). 'Fuyu 3' appeared resistant in the 2003 field test, but was susceptible in the 2004 field test, and lation in three greenhouse tests: zero of five, three of nine, and 0 of 10 plants were infected. The three infected plants expressed chlorotic spots (one plant), or very mild symptoms (two plants), contained PCRdetectable virus, and recovered from symptom expression.

The DREC planting in Fall 2003 was subject to very high whitefly pressure and it is unlikely that PI 313970 escaped infection as a result of low or nonuniform insect pressure. 'Fuyu 3', like PI 313970, was resistant in the 2003 field test, but it was clearly susceptible in the 2004 field test, and was susceptible in a greenhouse test (Table 2 ). Disease recovery may be a factor in the discrepancy between the 2003 and 2004 field tests. The 2003 test was evaluated $70 \mathrm{~d}$ after planting, whereas the 2004 test was evaluated $53 \mathrm{~d}$ after planting. The additional $17 \mathrm{~d}$ in 2003 may have been sufficient for PI 313970 to recover and appear asymptomatic. Resistance to SPW-B may be a factor in the resistance of PI 313970 to $\mathrm{CuLCrV}$; it has partial resistance to SPW- B (Boissot et al., 2003). Partial resistance to SPW-B in melon accession TGR-1551 did not, however, affect the resistance of TGR-1551 to Cucurbit yellow stunting disorder virus (López-Sesé and Gómez-Guillamón, 2000).

Inheritance of resistance in PI 313970. Segregation data in the 2003 and 2004 field tests and three controlled inoculation greenhouse tests indicate partial resistance to $\mathrm{CuLCrV}$ in PI 313970 resulting from a single, recessive gene. In 2003, PI 313970 was asymptomatic, but in 2004, 18 of 32 PI 313970 plants exhibited chlorotic spots (Table 3). In the greenhouse tests, 10 of 41 plants were infected. Of these, eight exhibited chlorotic spots only (Table 3 ).

Reciprocal $F_{1}$ families were, with the exception of some escapes in the field tests, susceptible, which indicated genetically recessive resistance in PI 313970 to $\mathrm{CuLCrV}$. Two $\mathrm{F}_{2}$ families (one family in the field tests and first greenhouse test, the other in the second greenhouse test) segregated in acceptable fits to a 3 susceptible : 1 resistant ratio (Table 3), indicative of a single recessive gene for resistance. The $\mathrm{BC}_{\mathrm{TM}}$ was susceptible in all tests (Table 3 ). The $\mathrm{BC}_{\mathrm{PI}}$ segregated in acceptable fits to a 1 resistant : 1 susceptible ratio in the 2003 field test and the greenhouse test, but not in the 2004 field test (Table 3).

Other putative resistance sources. Three other putative sources of resistance to $\mathrm{CuLCrV}$ were challenged in a greenhouse test along with 'Top Mark' and their $F_{1}$ families from crosses with 'Top Mark' (Table 4). PI 124111 appeared to be resistant in two initial greenhouse tests. Two of 13 inoculated plants expressed chlorotic spots (Table 2). Zero of five challenged plants were infected in the first test compared with five plants each of 'Top Mark', 'PMR 5', and WMR 29: and three of five plants each of 'Védrantais' and PI 414723. Two of eight PI 124111 plants in the second test exhibited chlorotic spots. In this test, four of seven 
Table 5. Reactions of susceptible 'Top Mark', resistant PI 313970, six other putative resistant cultigens, and $\mathrm{F}_{1}$ progeny from crosses with PI 313970 to Cucurbit leaf crumple virus in a greenhouse test.

\begin{tabular}{|c|c|c|c|c|}
\hline \multirow[b]{2}{*}{ Cultigen } & \multicolumn{4}{|c|}{ No. of plants } \\
\hline & Asymptomatic & Uncertain & Chlorotic spots & Symptomatic \\
\hline Top Mark & 3 & 0 & 0 & 6 \\
\hline PI 313970 & 9 & 0 & 0 & 0 \\
\hline MR-1 & 2 & 0 & 0 & 0 \\
\hline PI 124111 & 6 & 0 & 2 & 0 \\
\hline PI 124112 & 8 & 0 & 2 & 0 \\
\hline PI 179901 & 9 & 0 & 1 & 0 \\
\hline PI 234607 & 7 & 0 & 1 & 2 \\
\hline PI 236355 & 5 & 0 & 0 & 0 \\
\hline $\mathrm{F}_{1} \mathrm{MR}-1 \times$ PI 313970 & 10 & 0 & 0 & 0 \\
\hline $\mathrm{F}_{1}$ PI $124111 \times$ PI 313970 & 10 & 0 & 0 & 0 \\
\hline $\mathrm{F}_{1}$ PI $313970 \times$ PI 124112 & 3 & 1 & 0 & 0 \\
\hline $\mathrm{F}_{1}$ PI $179901 \times$ PI 313970 & 7 & 0 & 0 & 0 \\
\hline $\mathrm{F}_{1}$ PI $234607 \times$ PI 313970 & 10 & 0 & 0 & 0 \\
\hline$\underline{F_{1}}$ PI $313970 \times$ PI 236355 & 10 & 0 & 0 & 0 \\
\hline
\end{tabular}

PI, plant introduction.

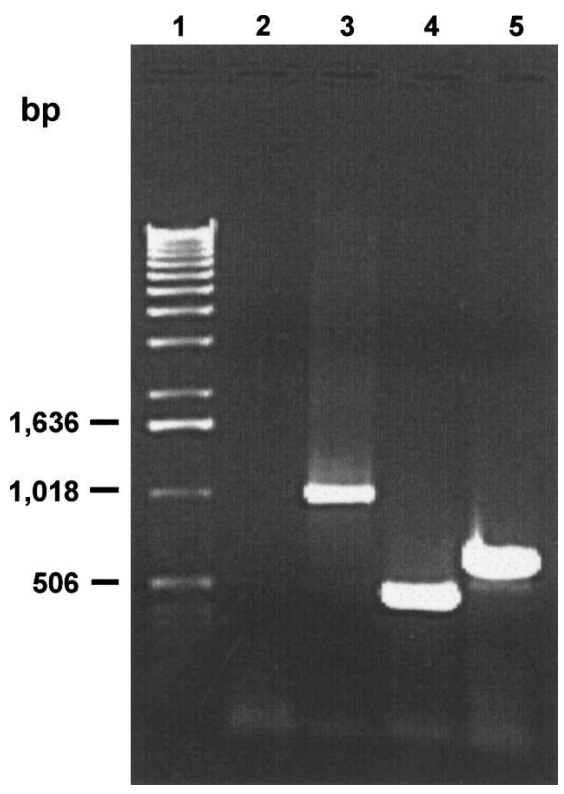

Fig. 2. A $1.0 \%$ agarose gel showing the products of polymerase chain reaction for detection of Cucurbit leaf crumple virus (CuLCrV) in melon leaf tissue with CuLCrV-specific primer pairs. Lane 1, BRL 1-kb ladder; Lane 2, from healthy melon leaf tissue; Lane 3 to Lane 5, from $\mathrm{CuLCrV}$-infected melon leaf tissue. The primer pair for lanes 2 and 3 was FB-1401 and RB-2437; Lane 4 was primers FA-908 and RA1-1419; Lane 5 was primers FA-908 and RA2-1601.

challenged PI 124111 plants were asymptomatic (Table 4). The F 1 PI $124111 \times$ 'Top Mark' gave similar results: about half asymptomatic and half symptomatic (Table 4).

One of 15 challenged plants of PI 179901 was infected in two initial tests (Table 2). It was completely asymptomatic in this test. The $F_{1}$ PI $179901 \times$ 'Top Mark' was susceptible (Table 3). Five of 12 challenged PI 234607 plants were infected in the two initial tests (Table 2), but the two plants challenged in this test were symptomatic (Table 4). The $F_{1}$ PI $234607 \times$ 'Top Mark' was susceptible (Table 4).
Six putative sources of resistance to $\mathrm{CuLCrV}$ were challenged in another greenhouse test along with 'Top Mark', PI 313970 , and $\mathrm{F}_{1}$ progeny from their crosses with PI 313970. 'Top Mark' was susceptible and PI 313970 was resistant (Table 5). MR-1, PI 124111, PI 124112, PI 179901, PI 234607, and PI 236355 were resistant; six plants total of PI 124111, PI 124112, PI 179901, and PI 234607 had chlorotic spots; and two plants of PI 234607 were symptomatic (Table 5). All six $F_{1}$ progenies from crosses with PI 313970 were resistant to $\mathrm{CuLCrV}$; only one plant in the $F_{1}$ PI $313970 \times$ PI 124112 had uncertain symptoms (Table 5). These data indicate allelism of the gene in PI 313970 with genes for resistance to $\mathrm{CuLCrV}$ in $\mathrm{MR}-1$, PI 124111, PI 124112, PI 179901, PI 234607, and PI 236355.

The uncertain symptoms, chlorotic spots, and recovery from visible symptoms observed in these studies reflect dynamic interactions at the cellular level between specific melon genotypes and $\mathrm{CuLCrV}$. Host plant RNA silencing, a type of gene regulation based on sequence-specific targeting and degradation of RNA (Vance and Vaucheret, 2001), is a possible recovery mechanism that may be affecting expression of resistance to $\mathrm{CuLCrV}$ in melon.

These field and greenhouse results demonstrated seven potential sources of resistance in melon to $\mathrm{CuLCrV}$. Partial resistance was evident in MR-1, PI 124111, PI 124112, PI 179901, PI 234607, and PI 313970. PI 236355 , which was not included in the field tests, did not exhibit any symptoms in two greenhouse tests and thus remains a potential source of immune-type resistance to CuLCrV. MR-1, PI 124111, PI 124112, PI 179901, and PI 313970 are vegetable-type melons, C. melo subsp. agrestis var. momordica (Pitrat et al., 2000), commonly grown in various parts of India. PI 234607 and PI 236355 are dessert melons. PI 234607 is from South Africa and is a C. melo subsp. melo var. reticulatus type, whereas PI 236355 from England is similar to Charentais-type melons (C. melo subsp. melo var. cantalupensis)
(Pitrat et al., 2000). PI 234607 or PI 236355 would, from the perspective of horticultural type, be the better choice as the resistant parent for development of a western United States shipping-type melon resistant to CuLCrV. Although PI 236355 exhibited a higher level of resistance than PI 234607 to $\mathrm{CuLCrV}$ in controlled greenhouse tests, their resistance to $\mathrm{CuLCrV}$ remains to be verified in naturally infected field tests.

PI 313970 resists numerous diseases and one insect that adversely affect melon production in the desert southwestern United States: six variants of $P$. xanthii races 1 and 2 (McCreight, 2006), the new $P$. xanthii race $\mathrm{S}$ that overcomes resistance to all the previously described sources of powdery mildew resistance in melon (McCreight and Coffey, 2007), lettuce infectious yellows virus (McCreight, 1998), and SPW-B (Boissot et al., 2003). Resistance to CuLCrV in PI 313970 was, therefore, emphasized in these studies despite its shortcomings for fruit quality (size, shape, and numerous rind and flesh characters) with respect to the U.S. market and seemingly lower level of resistance to $\mathrm{CuLCrV}$ compared with several other cultigens - notably, PI 236355. MR-1, also a vegetable-type melon, would be the source of choice for $\mathrm{CuLCrV}$ resistance where resistances to the following diseases are of interest: downy mildew incited by Pseudoperonospora cubensis (Berk \& Kurt.) (Thomas, 1985); P. xanthii races 0, 1 (six variants), 2 (three variants), 3, 4, 5, and G (McCreight, 2006; Thomas, 1986); Alternaria cucumerina (Ellis \& Everh.) Elliott (Thomas et al., 1990); and Fusarium oxysporum Schlechtend.:Fr.f.sp. melonis (Leach \& Currence) Snyd. \& Hans. races 0, 1, and 2 (Zink and Thomas, 1989). PI 236355, if confirmed in field and additional greenhouse tests, appears be the source of choice for $\mathrm{CuLCrV}$ resistance because of its horticultural similarity to western United States shipping-type melons, but it is highly susceptible to $P$. xanthii races 1 (three variants) and 2 (two variants) (McCreight, 2006), and race S (J.D. McCreight, unpublished data) in California and Arizona, although it was resistant to a Michigan strain of $P$. xanthii race 1 (Harwood and Markarian, 1968). PI 234607 remains a potential source of resistance to $\mathrm{CuLCrV}$. It is resistant to six variants of $P$. xanthii races 1 and 2 (McCreight, 2006), but is susceptible to race $\mathrm{S}$ in California and Arizona (J.D. McCreight, unpublished data).

Field and greenhouse tests demonstrated resistance to CuLCrV in PI 313970 as a result of a single, recessive gene. Resistance in three other cultigens (PI 124111, PI 179901, and PI 234607) appeared also to be conditioned by a recessive gene based on susceptibility of their $F_{1}$ progenies from crosses with 'Top Mark'. Nearly complete expression of resistance to $\mathrm{CuLCrV}$ in $\mathrm{F}_{1}$ progenies of crosses of PI 313970 with MR-1, PI 124111, PI 124112, PI 179901, PI 234607, and PI 236355 indicate allelism of the resistance gene in PI 313970 with the genes in the 
other six cultigens. The name cucurbit leaf crumple virus and symbol culcrv are proposed for this gene.

\section{Literature Cited}

Boissot, N., D. Lafortune, C. Pavis, and N. Sauvion. 2003. Field resistance to Bemisia tabaci in Cucumis melo. HortScience 38:77-80.

Brown, J.K. and H.S. Costa. 1992. First report of whitefly-associated squash silverleaf disorder of Cucurbita in Arizona and of white streaking disorder of Brassica species in Arizona and California. Plant Dis. 76:426.

Brown, J.K., A.M. Idris, C. Alteri, and D.C. Stenger. 2002. Emergence of a new cucurbitinfecting begomovirus species capable of forming reassortants with related viruses in the Squash leaf curl virus cluster. Phytopathology 92:734-742.

Brown, J.K., A.M. Idris, M.W. Olsen, M.E. Miller, T. Isakeit, and J. Anciso. 2000. Cucurbit leaf curl virus, a new whitefly-transmitted geminivirus in Arizona, Texas, and Mexico. Plant Dis. 84:809.

Brown, J.K., A.M. Idris, D. Rogan, M.H. Hussein, and M. Palmieri. 2001. Melon chlorotic leaf curl virus, a new begomovirus associated with Bemisia tabaci infestation in Guatemala. Plant Dis. 85:1027.

Brown, J.K. and M.R. Nelson. 1986. Whiteflyborne viruses of melons and lettuce in Arizona. Phytopathology 76:236-239.

Cohen, S., J.E. Duffus, R.C. Larson, H.Y. Liu, and R.A. Flock. 1983. Purification, serology, and vector relationships of squash leaf curl virus, a whitefly-transmitted geminivirus. Phytopathology 73:1669-1673.

Duffus, J.E., H.Y. Liu, and M.R. Johns. 1985. Melon leaf curl virus-a new gemini virus with host and serological variations from squash leaf curl virus. Phytopathology 75:1312. (Abstr.).
Flock, R.A. and D.E. Mayhew. 1981. Squash leaf curl, a new disease of cucurbits in California. Plant Dis. 65:75-76.

Guzman, P., M.R. Sudarshana, Y.S. Seo, M.R Rojas, E. Natwick, T. Turini, K. Mayberry, and R.L. Gilbertson. 2000. A new bipartite geminivirus (Begomovirus) causing leaf curl and crumpling in cucurbits in the Imperial Valley of California. Plant Dis. 84:488.

Harwood, R.R. and D. Markarian. 1968. A genetic survey of resistance to powdery mildew in muskmelon. J. Hered. 59:213-217.

Henneberry, T.J., N.C. Toscano, and S.J. Castle. 1998. Bemisia spp. (Homoptera: Aleyrodidae) in the United States history, pest status, and management. Recent Res. Dev. Entomol. 2:151-161.

ICTVdB Management. 2006. Squash mild leaf curl virus. In: C. Büchen-Osmond (ed.). ICTVdBThe Universal Virus Database, vers. 4. Columbia University, New York.

Jones, D.R. 2003. Plant viruses transmitted by whiteflies. Eur. J. Plant Pathol. 109:195-219.

Li, R.H., G.C. Wisler, H.Y. Liu, and J.E. Duffus. 1998. Comparison of diagnostic techniques for detection of tomato infectious chlorosis virus. Plant Dis. 82:84-88.

Liu, H.Y., S. Cohen, and J.E. Duffus. 1992. The use of isozyme patterns to distinguish sweetpotato whitefly (Bemisia tabaci) biotypes. Phytoparasitica 20:187-194.

López-Sesé, A.I. and M.L. Gómez-Guillamón. 2000. Resistance to Cucurbit yellowing stunting disorder virus (CYSDV) in Cucumis melo L. HortScience 35:110-113.

McCreight, J.D. 2000. Inheritance of resistance to lettuce infectious yellows virus in melon. HortScience 35:1118-1120.

McCreight, J.D. 2003. Genes for resistance to powdery mildew races 1 and 2U.S. in melon PI 313970. HortScience 38:591-594.

McCreight, J.D. 2006. Melon-powdery mildew interactions reveal variation in melon cultigens and Podosphaera xanthii races 1 and 2. J. Amer. Soc. Hort. Sci. 131:59-65.

McCreight, J.D. and M.D. Coffey. 2007. Resistance to a new race of the cucurbit powdery mildew present in Arizona and California. HortScience 42:1013. (abstr.).

McCreight, J.D., M.D. Coffey, T.A. Turini, and M.E. Matheron. 2005. Field evidence for a new race of powdery mildew on melon. HortScience 40:888. (abstr.).

McCreight, J.D. and A.N. Kishaba. 1991. Reaction of cucurbit species to squash leaf curl virus and sweetpotato whitefly. J. Amer. Soc. Hort. Sci. 116:137-141

McCreight, J.D., H. Nerson, and R. Grumet. 1992. Melon (Cucumis melo L.). p. 267-294. In: G. Kalloo and B.O. Bergh (eds.). Improvement of vegetable crops. Pergamon Press, Oxford.

Pitrat, M., P. Hanelt, and K. Hammer. 2000. Some comments on infraspecific classification of cultivars of melon. Acta Hort. 510:29-36.

Robinson, R.W. and D.S. Decker-Walters. 1997. Cucurbits. CAB International, NY.

Thomas, C.E. 1985. Resistant reaction of muskmelon line MR-1 against downy mildew. Phytopathology 75:504. (abstr.).

Thomas, C.E. 1986. Downy and powdery mildew resistant muskmelon breeding line MR-1. HortScience 21:329.

Thomas, C.E., J.D. McCreight, and E.L. Jourdain. 1990. Inheritance of resistance to Alternaria cucumerina in Cucumis melo line MR-1. Plant Dis. 74:868-870.

Vance, V. and H. Vaucheret. 2001. RNA silencing in plants: Defense and counterdefense. Science 292:2277-2280

Yates, F. 1931. Contingency tables involving small numbers and the $\chi^{2}$ test. Suppl. J. R. Stat. Soc. $1: 215-235$.

Zink, F.W. and C.E. Thomas. 1990. Genetics of resistance to Fusarium oxysporum f.sp. melonis races 0,1 , and 2 in muskmelon line MR-1. Phytopathology 80:1230-1232. 